\title{
PARTICIPATION OF ACTIVE SENIORS IN RURAL AREAS IN PUBLIC LIFE
}

\author{
Zuzana Bednaříková
}

Received 3 October 2011; Accepted 23 March 2012

\begin{abstract}
The paper presents the theme of voluntary senior participation in public life. A voluntary activity can be characterized as publicly beneficial voluntary work. Social administration plays its role in the care of seniors by means of social services provided as enterprise programs. Currently, there are few programs based on the active participation of seniors in public life using their expertise to provide leisure time, life or professional experience for the benefit of others. Especially in rural areas, active seniors can take advantage of the community planning of social services, Rural Area Regeneration Program or lump-sum actions. The case study analysis of the event "Seniors Welcome" provides a basis for communication with seniors, information on their needs, interests or reasons for refusing to participate.
\end{abstract}

Key words: active seniors, voluntary work, social administration

\begin{abstract}
Abstrakt: Příspěvek se zabývá problematikou možnosti participace aktivních seniorů na veřejném životě prostřednictvím dobrovolných aktivit. Dobrovolnickou práci Ize charakterizovat definicí veřejně prospěšného dobrovolnictví. $V$ péči o aktivní seniory sehrává svoji roli sociální správa formou poskytování sociálních služeb jako podnikatelských programů. V současné době existuje minimum programů založených na aktivní participaci seniorů na veřejném životě a využívajících jejich snahu poskytnout volný čas, životní a profesní zkušenosti ve prospěch ostatních. Zejména ve venkovských oblastech mohou aktivní senioři najít uplatnění v rámci komunitního plánování sociálních služeb, programu Podpora obnovy venkova nebo jednorázových akcí. Analýza případových studií z akce „Senioři vítáni“ poskytla podklady pro komunikaci se seniory, informace o jejich potřebách, zájmech i důvodech odmítnutí participace.
\end{abstract}

Klíčová slova: aktivní senioři, dobrovolnictví, sociální správa

\section{Introduction}

Demographic developments in Europe indicate a gradual aging of the population and most developed countries are trying to adapt to this trend (Trnková, 2005:111). For this purpose the Czech Republic has declared a National Program for the Preparation for Ageing for

\footnotetext{
${ }^{1}$ Ing. Zuzana Bednaříková, Institute of Agricultural Economics and Information), Mánesova 75, 12058 Prague 2 and Department of Regional Studies), Faculty of Economics and Public Administration), University of Economics Prague), nám. W. Churchilla 4, 13067 Prague 3, e-mail: bednarikova.zuzana@uzei.cz
} 
the period 2008 - 2012 (MLSA, 2011a). The basis for the implementation of this program is to change the attitudes of individuals and society as a whole. The ethical principles of recognition of seniors are respect of their dignity and personality, their independence and the right to make their own choices. A prerequisite for the maintenance or development of the social status of seniors is a natural social environment, because seniors are interested in spending the rest of their life especially in a familiar environment.

Ageing is not just a private matter, but it concerns the whole society, because it has many consequences for our population. Retirement changes the person's identity and it is very difficult for them to cope with the new situation, because it is full of uncertainties, primarily economic. One way to ensure the quality of life for seniors is for them to achieve maximum self-sufficiency. This is possible by keeping older people in good mental and physical condition, especially by organizing various activities and events for seniors. The problem of our population aging raises the discussion on the involvement of pensioners in different activities, and the active old age in general.

It is obvious that programs aimed at seniors focus almost exclusively on providing social and health services. There are very few programs that are based on the active participation of seniors in public life or that use their willingness to engage themselves for the benefit of others by providing some of their free time and offering their life and professional experiences.

In this article I will deal with active seniors, this means seniors who may participate in public life through voluntary activities. This article aims to find options that will allow active seniors to engage in public life through voluntary activities. This is a very hot topic both because of the growing numbers of old people, and because many seniors are interested in living an active life, they want to be useful, but cannot or do not want to be employed. The issue of the population aging especially affects rural areas, especially in small villages, where a worse age structure with a predominance of the elderly over those under 15 is evident.

\section{The issue of aging in the Czech Republic}

Currently pensioners represent a quarter of the population of the Czech Republic, and as a result of demographic aging, this group will further grow in size (Pollnerová, 2006: 226). Pollnerová (2006) further states that the proportion of pensioners since 1989 has not increased much, in the forthcoming years however, we can expect higher increases of the number of pensioners mainly due to the faster growth in the number of people entitled to old-age pensions. According to data from the Czech Social Security Administration, in the period 1998 - 2011 the number of old-age pensioners increased by $18.9 \%$, i.e. to $2,280,450$ (CSSA, 2012) old-age pensioners (see Figure 1).

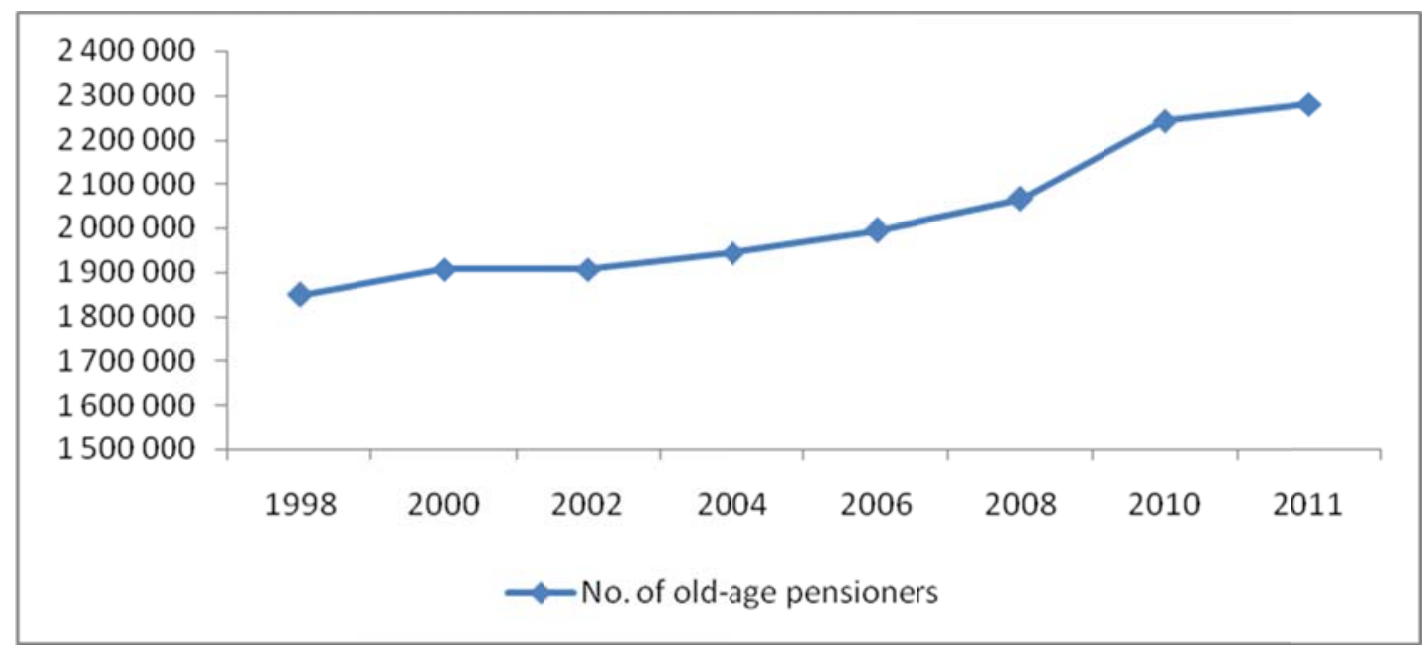

Fig 1. Number of old-age pensioners in the Czech Republic, 1998 - 2011. Source: CSSA, 2012. 
The aging of the population is the most characteristic feature of the demographic developments in the Czech Republic and other developed countries in Europe. The increasing number of older people, however, due to the increased education level and the improving health of the population, constitutes a potential for social and economic development. Policies preparing for this should therefore respond to two basic challenges: to integrate the elderly into the economic and social development and create an age-inclusive society which eliminates a negative view of old people as social burden. It is important to adapt employment policies, pension policies and other policies and services to the ongoing social and demographic changes.

The main principles of the policies necessary for the preparation for aging from the perspective of the Ministry of Labour and Social Affairs are: an emphasis on human rights, respect for the gender aspect of aging, a lifelong approach to aging and health, an emphasis on family and intergenerational relations, the creation of measures based on research-based knowledge and relevant statistical data, with special attention paid to minorities (disabled seniors, those suffering from dementia, the mentally ill, elderly people from ethnic minorities, etc.), while respecting the differences between rural and urban areas (MLSA, 2011a).

In particular, seniors in rural areas find themselves in a relatively difficult life situation. Majerová (2005: 7) points out that the seniors have often lived most of their lives in the countryside, they have close economic and emotional relationships to it, i.e. they usually own a house or an apartment, a garden, a small farm, etc., which constitute a source of quality and cheap food. They are accustomed to their village and its surroundings and in close proximity to their relatives and neighbours. With the years, however, they grow less and less self-sufficient, and the countryside usually does not offer enough easily accessible and quality social and medical care. Travelling to larger towns or villages is difficult for them. If there are people, such as relatives, living in the village or its neighbourhood who are willing and able to help, the old people's situation is not critical. The situation is worse in the case of seniors who depend on themselves.

Given the increasing number of pensioners, the life cycle issues also concentrate on the social integration of older people, which includes the issue of employment of people of retirement age (Hamplová and Pollnerová, 2006: 239). Below, I will talk about this issue from a different point of view. It will not be about the inclusion of pensioners in the work process, but about the involvement of seniors in an active way of life through voluntary activities. According to Sýkorová (2007) an essential strategy for seniors is „to be as active as before“, „to do what they normally do", which means to take care of the household, to develop contacts and relationships with their loved ones, to engage in the lives of their children, to be useful to others, to take up their interests and hobbies, to follow what is happening in society, possibly to go to work or to educate themselves, and ultimately to make decisions independently and to carry personal responsibility for themselves and their situation.

Laslett (1996) or Gilleard and Higgs (2000) have dealt with the presumption of active age when active age replaces the picture of seniors as passive, infirm or sick. According to Katz (2000) is seniors' activity connected with their participation in labour market, self-education and active spending of old-age period in general. So, activity has become an integral part of present seniors.

\section{The role of social administration in the care for active seniors}

Social administration in a broader sense can be characterized as a set of bodies and organizations that are active in the social sphere and implement social policies through employing certain tools, resources and techniques. Social policy can also be perceived in a broader sense, i.e. as the policy of social organizations. The tools, means and techniques of social policy implementation can be collectively referred to as benefits and services of a social nature (Tomeš, 2002: 36).

The social administration systems are defined units with a specific social objective (a defined mission), with a certain organization, organized structures of people and a certain set of tools and funds, through which they attempt to achieve their goals. The social activities (system 
elements) within the social administration systems are arranged according to the socially recognized needs of clients into sets of activities by assigning to them:

- organizational structures of people who decide on the activities and carry them out;

- tools (benefits, services or commands and prohibitions);

- resources from which the activities are financed.

Social administration systems can be divided by:

- $\quad$ who owns them - into the private and public (state, autonomous);

- $\quad$ their economic nature - into commercial systems (profitable) and civil systems (non-profit);

- the clients whom they serve - into the civil and the occupational;

- the field of activity into:

- work and employment systems (employment offices, employment services, work safety offices, etc.)

- social security systems (social insurance, state social supports, social assistance, social services, etc.);

- medical support systems (health insurance, sanitary protection, basic public care, etc.);

- educational and school systems (compulsory education, social scholarships, etc.) (Tomeš, 2002: 48).

In social administration only formalized bodies and organizations with defined organizational rules, structures, with systematic and targeted activities and defined processes and outcomes can be active. Individuals can create such organizations. Individuals, such as random donors or informal and random groups of people cannot be considered social administration bodies (Tomeš, 2002: 62).

In terms of the focus of this work it is important that, according to Tomeš (2002: 73), social activities and the provision of social services can also be business programs. It is possible to do business in the social field. To do business means to organize a service, which is welcome in the social field. It is possible to have not-for-profit businesses, only to cover salaries and expenses, as well as those motivated by profit. Social services for the state or citizens can be performed for a fee while also achieving a profit. The social nature is that these services are also accessible to those who cannot afford them, and for such people payment comes from other sources. Some businesses support or sponsor social activities, even outside their own area, through gifts or provision of services.

Apart from the state social organizations that aim to help citizens include civic associations, foundations, interest groups and church organizations, and support associations. Their social program is the target, not just the means to achieve other objectives. Nevertheless, profit is not the goal of their efforts.

These organizations and others (e.g. municipalities, libraries, etc.) can work as, among other things, agents for the projects that focus on creating offers for the application of active older people through a variety of voluntary activities that will allow them to actively participate in public life.

Here we need to clarify what, in this context, the concept of voluntary activity means. Somrová and Klégrová (2006: 5) state that "the concept of volunteering is often used in connection with the activity of volunteers, however, in publications on this subject often it is not explained what exactly the authors include in this word. Most authors use this term to refer to the voluntary activity itself".

The authors, Somrová and Klégrová (2006), divide volunteering according to various criteria: in terms of time, according to the social life area in which it happens, according to the role they play in the organization, by origin, etc. They also point to a possible division of volunteering into 
voluntary civic assistance, mutually beneficial volunteering, public service volunteering, and voluntary service.

„Voluntary civic assistance is a voluntary activity within the family, relatives, friends and neighbours. It is characterized by spontaneity, unexpected financial evaluation (as, after all, any other voluntary activity) and by the fact that the person who carries it out takes it for granted.

Mutually beneficial volunteering means a voluntary activity within the community - village, parish, club or association. This activity is carried out by members of the community in the realization of common goals and interests, and is mainly for the benefit of members of the community. The most striking example of mutually beneficial volunteering is an association activity.

Public service volunteering is a voluntary activity for the benefit of others, which is similar to paid work in the sense that the volunteer has a defined activity, to which he/she is devoted and which must be done, so that the beneficiary can rely on it. In contrast to the mutually beneficial volunteering, the priority of this type of volunteering is to be useful to one's surroundings. The work of many non-profit organizations is built on this kind of voluntary activity and its organization is carried out by voluntary centres.

This activity can play its role only when it is properly organized, and when the role of the volunteer and his/her relationship to the employees of the organization are defined. The volunteer needs to know clearly the organization's mission, be well good trained and feel a personal responsibility for the work he/she performs.

Voluntary service is usually a long-term (up to several months) commitment to engage in voluntary work, often outside one's own country. It has many features in common with community service volunteering. What's important here is the long duration of the service and the formalized relationship to the organization that sends the volunteer and that he/she works for" (Somrová a Klégrová, 2006: 7-8).

Active aging is central also in the European political agenda. The EU strategy for growth for the period 2010 - 2020 includes also promoting active aging due to rapidly rising share of older people. The aim of this approach is to "to create more opportunities for older people to stay longer in work, to contribute to society as volunteers and carers and to remain independent for as long as possible" (European Commission, 2011: 5).

Senior Volunteering Programme run under Grundtvig describes that "volunteering has been recognised as a way of offering new learning opportunities to senior citizens in Europe, promoting the process of active ageing and emphasising the contribution of seniors to our societies. Indeed, senior citizens are a rich source of wisdom and experience from which society should derive far greater benefit than has usually been the case in the past." (European Commission, 2011: 41).

The definitions of public service volunteering or described by Senior Volunteering Programme are very well characterized by the concept of voluntary work that is used in connection with the involvement of active seniors in public life. In addition, it should be emphasized that this is an unpaid activity. Therefore the good feeling of a job well done and the need to be beneficial to one's surroundings are gaining in significance. Encouraging community service voluntary activities for active seniors may also contribute to the elimination of the negative view of old people that for many may represent a social burden.

\section{Possibilities of active seniors' involvement in public life in the Czech Republic}

The issue of the involvement of active seniors in public life is not dealt with to the same extent as the attention paid to the provision of social and health services for them. Still, there are programs that deal with this. 


\section{Community planning of social services}

The Guide through the Process of Community Planning of Social Services, which is available on the website of the Ministry of Labour and Social Affairs (MLSA, 2011b) states the objective of community planning of social services is: "so that people have at their disposal such social services they need. It is therefore about both offering a range of different types of services, their local availability, and enhancing their quality. At the heart of the community planning of social services there is the involvement of all those whom the social services concern and who wish to contribute to their improvement, i.e. their users, providers, clients and the public. It is a process based on negotiation and cooperation between these parties, and thus constitutes the planning of services based on reality. Therefore, the key is discovering the needs and views of people regarding social services and their functioning (not just the current users, but also the general public as the potential users of the services).

Social service providers are entities that provide and offer services, regardless of whether they are, for example, non-governmental non-profit organizations or organizations established by a municipality, a county, or the state" (MLSA, 2011b).

The planning takes place at the municipal level, i.e. at the lowest level, and thus it is possible to create a system of services under existing and anticipated needs, of an adequate quality and in accordance with local characteristics. This means that the people themselves participate in the planning of what suits them and will meet their needs. Since most municipalities voluntarily associate in unions - micro-regions, it is also possible to carry out community planning at this level.

Community planning thus represents an opportunity not only for organizations, but also for active seniors themselves to point to their willingness to participate in the public life of the village, or the micro-region, and to contribute to the expansion and improvement of social services in the village.

\section{Rural Renewal Support}

The Rural Renewal Support program, which is within the remit of the Ministry of Local Development and is the responsibility of the individual regions, aims to support rural renewal and development. This program presumes the participation of rural people, civil societies and associations in the renewal of their community in accordance with local traditions. It is also important to emphasize that the costs of implementing the event can be covered by voluntary work by citizens of the municipality. It offers the opportunity for active seniors to voluntarily participate in the broad spectrum of events which may include: restoration and maintenance of rural buildings and amenities, restoration and establishment of public green areas, construction or reconstruction of local roads footpaths or public lighting, renovation or construction of facilities for leisure activities, etc.

\section{Seniors Welcome program}

"Seniors Welcome" is the name of the collection of case studies, which represent the output of the joint program of the Česká Sporitelna Foundation and the Open Society Fund (OSF) Praha Foundation (Open Society Fund Praha Foundation, 2008). According to Ing. Jana Pártlová (Open Society Fund Praha Foundation, 2008: 131), the Manager of the Seniors Welcome program, the meaning of the program was "to clarify and promote the role of seniors in society, to highlight the potential of the professional and life experiences of seniors and their willingness to engage themselves for the benefit of society and thus help eliminate negative stereotypes associated with this group.

The main goal of the program is to show examples of various possibilities for the active involvement of seniors in various activities on the local level. Organizations were invited to participate in the competition for the endowment of projects that would offer active seniors activities that would appeal to them and through volunteering engage them in public life."

I cannot say with certainty, whether it is a rare program, but after reading the individual case studies it is clear that the program is unique both because it attempts to involve seniors in public 
life, and because of the wide spectrum of individual projects that have received the endowment. It is surprising how many possibilities there are for the involvement of seniors in various activities and for using their expertise and skills. Here are some examples of the case studies:

- a group of witnesses recorded their own memories and from them create an unconventional tour guide of the city of Rožnov (library, Rožnov p. Radhoštěm);

- seniors organize the Academic Year for Seniors and participate in the preparation of other activities of the library (library, Vsetín);

- using the potential of active seniors for community service activities in the library (library, Sedlčany);

- seniors map the monuments in the city of Vítkov and its surroundings and prepare the material for printing a tourist guide and a calendar (city of Vítkov);

- the involvement of seniors and children in cultural and social events and public affairs - e.g. workshops, taking care of public spaces (city of Nové Hrady and the Cultural and Information Centre);

- the involvement of seniors in public life - handmade, cognitive and educational activities. An original method of addressing active seniors - seniors 'seekers' appeal to their peers (Community Centre, České Švýcarsko/Czech Switzerland);

- the involvement of seniors in saving/restoring school gardens (public service company, Chaloupky);

- the participation of seniors in the management or assistance with activities for children and youth, including crime prevention (Frýdlant Roma Civic Association, Frýdlant area);

- the involvement and voluntary work of seniors in the Basic Organization of the Czech Union for Nature Conservation Vlašim (CUNC, Vlašim);

- seniors invited to co-run the Dřevěnka - during the organization of new cultural events, with the guiding service, as serving assistants in the tea shop and coffee shop, cleaning and restoration of exhibits (Civic Association Chalupění, Úpice);

- seniors as volunteers, who make the hospice clients' stay more pleasant (Hospice of St. John N. Neumann, Prachatice);

- seniors as volunteers at the Sue Ryder Home, public service company, which provides social services for seniors in difficult health and social situations (NGO Sue Ryder Home, public service company, Prague);

- seniors as volunteers dedicated to supporting and communicating with patients, including children (Lékořice Civic Association, Prague).

The number of seniors involved in individual projects varies from 10 to 30 . One of the successful projects that are worth mentioning was the participation of seniors in the assistance or management of activities for children and youth organized by Frýdlant Roma Civic Association. 15 seniors on the average participated in this project. Hobby groups were focused on children coming from social deprived society. The main goals of the project were the facilitation to active seniors to participate in a social life and crime prevention through the offer of hobby groups. The main project activities included hobby groups led by seniors such as tutor classes, sewing, embroidery, painting, ecology, cooking, dancing. Despite the initial problems with communication with seniors (neglect of negotiated meetings, verbal instructions or agreements) the final outcome of the project was positive. Seniors were disposed to continue in leading hobby groups and the spectrum of hobby groups has been extended in the following year.

On the other hand, here is the example of less successful project. The core of the project's failure lies in the choice of activity. The project was based on the cooperation with hospice clients' in Hospice of St. John N. Neumann in Prachatice). The main activity was to make the hospice clients' stay more pleasant. Probably, the fear of the hospice theme and 
a projection of the self-age were the main problems why only few seniors were disposed to participating in this project.

Several conclusions can be drawn from the case studies that can serve as a certain guide in the preparation of other projects involving active seniors in public life. The best and most effective way to reach seniors is to address them directly, preferably an individual approach, explaining exactly what is required of them and what is expected. The appropriate way of addressing seniors proved to be addressing them via seniors already involved. The effect of other ways of addressing, such as posters, handouts, regional media (newspapers, TV), press conferences, or project presentations was significantly lower.

It is important to emphasize the meaning of the expected activity that is expected from the seniors, to take into account their health and time flexibility. Many seniors fulfil other obligations, such as babysitting their grandchildren, gardening, and these also need to be respected.

The director of the OSF Praha, Ing. Marie Kopecká (Open Society Fund Praha Foundation, 2008: 150) ,,highlights the positive impact of the program "not only on the seniors themselves, the participants in individual projects to whom it gave a sense of usefulness and recognition, but it also changed the public's perception of seniors from passive recipients of services to that of active participants in public life“.

However, the evaluation of individual projects also showed that many seniors are not interested in active participation in public life for various reasons: health problems, lack of time, distrust in the project, fear of new activities and, last but not least, the unwillingness to work for free. Also the interest in activities varied, the work with hospice clients, i.e. with old and sick people was not one of the preferred activities. The spectrum of organizations that implemented the project was very diverse: libraries, the city, cultural and information centres, community centres, public service companies, civic associations. However, libraries and civic associations prevailed.

\section{Conclusion}

The problems with involving active seniors in public life based on volunteering is an issue that is currently not dealt with often. Nevertheless, it is possible to find ways to apply the skills and knowledge of seniors who want to help others and invest part of their time in various useful activities. Community planning and the Rural Regeneration Support program can be regarded as repeated appeals. The "Seniors Welcome" project, although a single event, may represent a template for organizing similar projects.

Seniors try to be active, self-sufficient and independent as long as possible, but within limits caused, especially, by changes in health and physical performance. Seniors experience the process of aging differently and have different ways of coping with it. The following approach associated with coping with old age, largely characterizes seniors who have participated in voluntary activities under the Seniors Welcome program.

The "Balanced Old Age" approach (Sýkorová, 2007) is characterized by the "wise" and balanced acceptance of old age and of current and anticipated restrictions related to it, clearly given by the loss of the internal potential of individuals (health, energy). Retirement is seen as a time of freedom, of time to "think of oneself", and also of being useful to others in the family and beyond it. Seniors look for positive aspects of life, they are active within their limits - they travel, have cultural interests, engage in volunteering, etc.

References

[1] Czech Social Security Administration. Důchodová statistika Available at: http://www.cssz.cz/cz/informace/statistiky/duchodova-statistika/. Retrieved 31.1.2012.

[2] European Commission (2011). How to promote active ageing in Europe. EU support to local and regional actors. Committee of the Region. Brussel. 
[3] Gilleard C. \& Higgs P. (2000). Cultures of Ageing: Self, Citizen and the Body. London: Prentice Hall.

[4] Hamplová D. \& Pollnerová Š. (2006). Pracovní trh v důchodovém a předdůchodovém věku. In Životní cyklus - sociologické a demografické perspektivy (pp. 239-246). Praha: Sociological Institute of the Academy of Sciences of the Czech republic.

[5] Katz S. (2000). Busy Bodies: Activity, Ageing and the Management of Everyday Life. Journal of Ageing Studies, 14(2), 135-152. Doi: 10.1016/S0890-4065(00)80008-0.

[6] Laslett P. (1996). A Fresh Map of Life: The Emergence of the Third Age. $2^{\text {nd }}$ edition. London: Macmillan Press.

[7] Majerová, V. et al. (2005): Český venkov 2004. Život mladých a starých lidí. Praha: Czech University of Life Sciences.

[8] Ministry of Labour and Social Affairs. Národní program prripravy na stárnutí na období 2008-2012 Retrieved at 7.3.2011 from: http://www.mpsv.cz/cs/2869.

[9] Ministry of Labour and Social Affairs. Průvodce procesem komunitního plánování sociálních služeb Retrieved at 17.4.2011 from: http://www.mpsv.cz/cs/849.

[10] Open Society Fund Prague (2008). Senioři vítáni - sborník prípadových studií. Praha: Otevřená společnost, o. p. s.

[11] Ministry of Regional Development. 117D815 - Podpora obnovy a rozvoje venkova Zásady podprogramu pro poskytování dotací $v$ roce 2011. Retrieved at 15.3.2011 from http://www.mmr.cz/Regionalni-politika/Programy-Dotace/Podpora-rozvoje-regionu-v-roce-2011/Podpora-obnovy-a-rozvoje-venkova.

[12] Pollnerová, Š. (2006): Změny v počtu a struktuře důchodců a jejich důchodových příjmů po roce 1989 (pp. 226-238). In Životní cyklus - sociologické a demografické perspektivy. Praha: Sociologický ústav Akademie věd České republiky.

[13] Somrová L. \& Klégrová A. (2006). Dobrovolnictví. Praha: Vzdělávací institut ochrany dětí.

[14] Sýkorová D. (2007). Autonomie ve stáři. Praha: Sociologické nakladatelství.

[15] Tomeš I. et al. (2002). Sociální správa. Praha: Portal.

[16] Trnková V. (2005) Aktivní strategie mladých a seniorů na venkově. In Majerová V. et al., Český venkov 2004. Život mladých a starých lidí (pp. 93-115). Praha: Czech University of Life Sciences. 